\title{
Chapter 11 \\ The Letter Thief: From Playing to Teaching to Learning to Playing
}

In a key passage of his writing on the development of written language in the child or what today could be referred to as a part of literacy development - Vygotsky (1997) emphasizes that "Reading and writing must be needed by the child" (p. 145). Elaborating on this idea, he argues that:

[T]his means that the best method for teaching is one in which the children do not learn to read and write, but in which both habits are the subject of play. For this, it is necessary that the letter become the same kind of element in the life of the child as, for example, speech is. [-] The natural method of teaching reading and writing consists of appropriately affecting the situation in which the child finds himself. The child must need reading and writing in his play. (p. 146).

Rather than being taught through explicit instruction and drill, what Vygotsky here argues is that how we make children participants in important cultural practices, such as reading and writing, is through cultivating in play activities the skills necessary for these forms of participation. Conceptual knowing such as reading, according to this perspective, needs to be necessary for the child in the activities in which she engages. For example, in order to initiate, participate and particularly develop a play, such as playing shop, being able to make graphical symbols (e.g., to show prices) that are possible for others to interpret are functional. From this perspective, Vygotsky concludes that "it would be natural to teach writing at a preschool age" (p. 143). He thus locates the developmental space about which we intend to make contributions from empirical research: how to teach in play-based activities where conceptual knowing is contextualized (van Oers, 1998) in manners relevant to ongoing (and developing) play. Introducing cultural tools and practices that are necessary for play becomes critical to play-responsive teaching. In this chapter, an example of such tools introduced in play by the teacher will be given. 


\section{The Letter Thief}

The activity to be analysed in this chapter is an example of child-initiated play called The Letter Thief. ANNIKA, who is one of the participating teachers in the activity, has described the background of the activity to be analysed as follows:

Some children [aged four to five] had played the board game The Letter Thief and in the game, there was a thief, a character, which steals letters. The children talked about the character but we [the teachers] had not had the opportunity to get involved in the activities/ communication of this theme. One day, several children were gathered around a table where some children were drawing maps in order to find the Letter Thief. One of the children wrote down letters the thief had stolen.

The activity that evolves is interesting since it illustrates play and learning and their relation, and what we refer to as play-responsive teaching: a child-initiated activity in which teachers (in different ways) become involved and participate; an academic skill as a content (to become aware of phonetics in order to, more generally, learn to read) within a play frame (as if) which continues to develop during (and potentially in extension of) the activity - centred around the challenge of what happens to a person's name when the thief steals the initial letter.

The content of learning the teaching is oriented towards is to discern the initials of names (and names as made up by combinations of individual letters), both graphically and phonetically. This will prove to be challenging to the children. ${ }^{1}$ The teachers scaffold the learning process and the development of play through meta-communicating outside the play frame, talking as is. In the activity, we can follow how one child, Maria, learns to separate the initial letter from a name as a whole. This also implies understanding something of the grapheme-phoneme relation; when a certain grapheme is changed (or "stolen" within the play frame), the phonetics of the name also changes. The learning process that analytically can be shown to take place can be theorized as a changed way of participation in a cultural practice (Lave \& Wenger, 1991).

\section{Processes of Participants Orienting Toward Temporarily Sufficient Intersubjectivity}

The video-recorded activity has been analytically differentiated into four sections. In the first one, we show how a shared play activity is established. In the second section, the content of learning is at the forefront of the participants' concern. The third section focuses the learning process of one of the participating children, Maria.

\footnotetext{
${ }^{1}$ The video camera, held by one of the teachers, focuses on the activity, that is, what the children are drawing and writing. Consequently, the child who speak is not always possible to identify and neither is the exact number of children who are present in the room. This is the reason why most of the children are referred to as "child" instead of by name in the transcripts.
} 
In the last section, we follow how the content of learning and, at the same time, the play frame, are extended by participants.

\section{Establishing a Shared Play Activity}

Through three excerpts from the video recording, we will present how a collaborative play activity is established and how the teachers become involved. The starting point of the teacher's involvement is her showing an interest in the children's play (see turn 2 below).

\section{Excerpt 11.1: Orienting Towards Temporarily Sufficient Intersubjectivity}

\begin{tabular}{c|l|l}
\hline 2. & LINN: & What are you doing? \\
\hline 3. & Children: & $\begin{array}{l}\text { We're doing the Letter Thief! (several children talk at the same time) And look, } \\
\text { the thief has stolen our letters! }\end{array}$ \\
\hline 4. & LINN: & Okay! \\
\hline 5. & Child: & Look (shows the paper) \\
\hline 6. & LINN: & Where is the Letter Thief? \\
\hline 7. & Child: & That. That's when he sleeps and that's him (points at the drawing) \\
\hline
\end{tabular}

The children are engaged in an activity where one girl is drawing and the others around her are commenting on what she draws. The teacher (handling the video camera) initiates participation by posing a question (turn 2). The children respond to this initiative by answering: "We're doing the Letter Thief! and look, the thief has stolen our letters!" (turn 3). The teacher confirms the explanation: Okay! (turn 4), which is sufficient here in order to establish a shared activity. One of the children further uses the drawing (see Fig. 11.1), a central part of the activity, for explaining what is going on. The teacher elaborates the play by asking within an as-if mode: "Where is the Letter Thief?" (turn 6) - indicating that she is in on the activity - and the child that holds the pen develops the narrative of the play by explaining the drawing (turn 7). In other words, meta-communication (as if) is used for establishing some initial intersubjectivity.

\section{Excerpt 11.2: The Letter Thief in Terms of as If or as Is}

\begin{tabular}{c|l|l}
\hline 9. & Child: & $\begin{array}{l}\text { He cannot be naked! (starts drawing on the paper, as if she put clothes on the Letter } \\
\text { Thief, see Fig. 11.1). He's a guy (several children laugh, say something inaudible) }\end{array}$ \\
\hline 10. & Child: & $\begin{array}{l}\text { He's already wearing... (turns the drawing so that the children around the table can } \\
\text { see) }\end{array}$ \\
\hline 11. & Child: & A dress (laughs) \\
\hline 12. & LINN: & How do you know it's a guy? \\
\hline 13. & Child: & Eeh, 'cause he's got a mustache (laughs) \\
\hline 14. & LINN: & Have you seen him? \\
\hline
\end{tabular}




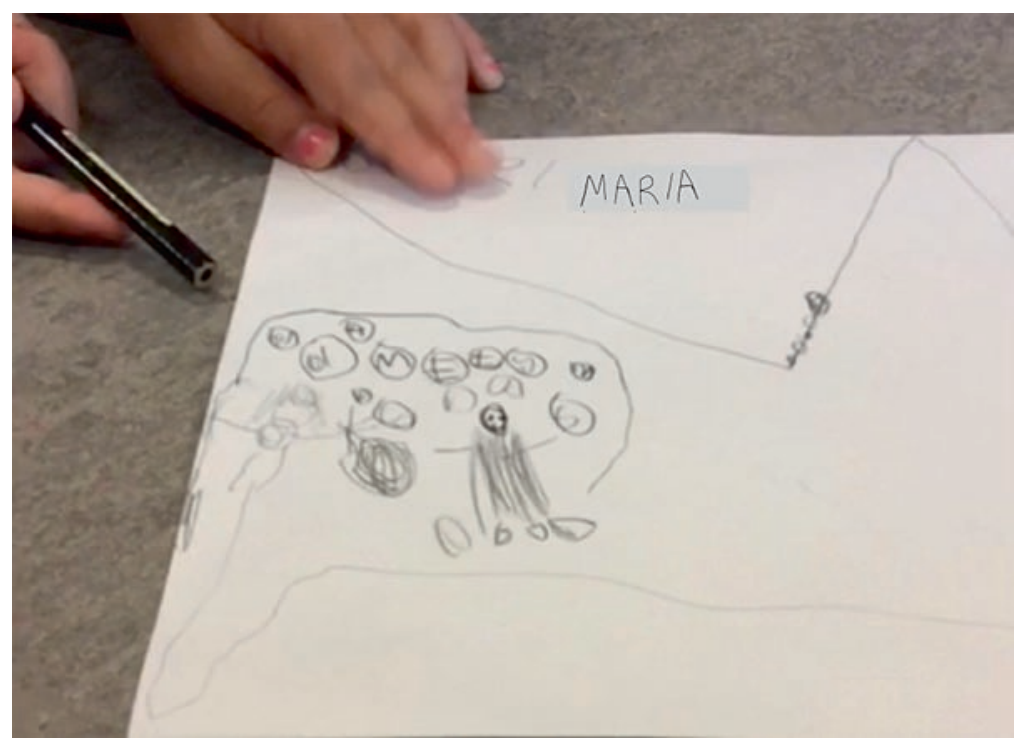

Fig. 11.1 The drawing the children are engaged in representing the Letter Thief (twice) and the letters he has taken. The drawing of the letter thief on the left side of the paper is made when talking about the character's looks and clothing (see turn 9). (The drawings have been edited so that the writings that identify the children's names are changed.)

15. Child: No, but I know so. 'Cause he's wearing a glued-on-mustache)

16. LINN: Okay. Have you seen him for real?

17. Child: No, but I know so. He, 'cause we have him in a game

In the negotiation about how the drawing should be understood within the play, the perspectives of $a$ s if and as is are alternated. The child who has drawn the picture of the Letter Thief says that: "He cannot be naked!" (turn 8). Two ways of understanding are opened up for, one about the visual representation of the Letter Thief on the paper (turns 10-11), and one of the model thief, that is, the character in the original board game (turns 15 and 17) the children have common experience of. The section represented by this excerpt illustrates how intersubjectivity is temporarily lost. The teacher scaffolds the interaction by posing a meta-question that helps the children to resolve the potential misunderstanding of what they each mean (turn 12): "How do you know it's a guy?" In response to this question (turns 13, 15 and 17) it is evident that the child who answers does not mention the drawn thief but the original character from the board game. When the teacher further asks whether the child has seen the thief "for real" (turn 16) she challenges the as-if dimension of the activity by implying that the character might be real. The excerpt shows how the teacher and some of the children have partly different ideas about the activity and more specifically about the central character, the thief, as to its look and clothing. 


\section{Excerpt 11.3: Re-establishing the Play Activity}

\begin{tabular}{c|l|l}
\hline 22. & Maria: & Let's start over. Who wants to take part? \\
\hline 23 & Children: & Me! \\
\hline 24. & Maria: & $\begin{array}{l}\text { (inaudible)... Olle, Liv and (makes a ring on her paper for every name she } \\
\text { mentions) }\end{array}$ \\
\hline 25. & Child: & Maria \\
\hline 26 & Maria: & And me. I'm the biggest (draws) \\
\hline
\end{tabular}

One of the children re-initiates the play by a comment and a question: "Let's start over. Who wants to take part?" (turn 22). This can be interpreted as a solution to a situation where the children have not established temporarily sufficient intersubjectivity; instead of further arguing, they start over. The other children respond by stating their participation (turn 23), which shows them accepting the suggestion to cease negotiating about the character. In this way, common agreement is established, momentarily regaining intersubjectivity to be able to go on with a (new) joint activity.

\section{Establishing Intersubjectivity About a Content of Learning}

In the following, we will show how the content of learning is initiated by a child and how she involves the teacher, LINN, to continue participating in the play activity. LINN takes on this opportunity to play the game and also to develop it further by challenging the children to note the difference a stolen initial makes to a name. By doing so a clear content of learning is 'planted' in the play (see turn 31 below).

\section{Excerpt 11.4: A Content of Learning is Foregrounded}

\begin{tabular}{l|l|l}
\hline 28. & Child: & $\begin{array}{l}\text { LINN, the letter thief has stolen L. LINN, the letter } \\
\text { thief has stolen L. }\end{array}$ \\
\hline 29. & LINN & The thief? \\
\hline 30. & Child: & Yes, it has stolen your letter! \\
\hline 31. & LINN: & $\begin{array}{l}\text { Oh no! Then what is my name? ...if I no longer have } \\
\text { an L? }\end{array}$ \\
\hline 32. & Child: & (inaudible) \\
\hline 33. & LINN: & Then what is my name if I don't have any L? \\
\hline 34. & Child: & (says several words starting with 'lin') \\
\hline 36. & LINN: & INN \\
\hline 37. & Maria: & inn! \\
\hline
\end{tabular}

The child's action within the play frame, in addressing the teacher, is an additional example of how the children pursue the play. A child invites the teacher (turn 28). She proves to be knowledgeable within the field of letters, by expressing that $\mathrm{L}$ 
is LINN's initial. Another child elaborates on this in terms of "letter" (turn 30). The teacher indicates that she is responsive to the play by crying out "Oh no!" (turn 31) when she is informed that the letter thief has taken 'her letter'. That is, she acts and participates as if, within the play frame. It is the teacher who introduces the challenge that is new in the play activity, to direct the attention to how a name sounds without the initial letter present, by asking what her name will be without the letter $\mathrm{L}$ (turns 31 and 33). This challenge is introduced within the play frame. This constitutes an important example of how a content of learning, in the form of an academic skill, can be introduced in a child-initiated play frame, without interrupting the play. That the content is new and challenging is shown by the children saying words that begin with the same letter(s) as Linn (L): "lin" (turn 34) and "lilla" (turn 37). Intersubjectivity is here lost due to the different 'levels' of understanding the initiated challenge. The teacher handles this by telling the 'right answer': "INN" (turn 35 ), which can be regarded as a way of guiding the children to a certain way of understand the rules of the play, and the concept of initial. One of the children, Maria, repeats what the teacher says: Inn! (turn 36), while another child does not indicate to have picked this up; instead suggesting a word starting with L (turn 37).

\section{Maria's Changed Participation During the Activity}

In the following five excerpts, we will show how one of the children, Maria, deals with the new challenge of handling symbols (letters) and their sounding representations.

\section{Excerpt 11.5: Meta-communication Within the Play}

\begin{tabular}{l|l|l}
\hline 38. & ANNIKA: & $\begin{array}{l}\text { Then what is your name Maria if the letter thief has stolen your M? ...if the M } \\
\text { is gone from Maria (silently sounding the name), then what is it? }\end{array}$ \\
\hline 39. & Maria: & Maria (inaudible) \\
\hline 40. & Olle: & (inaudible) my O? \\
\hline 41. & ANNIKA: & What happens then? \\
\hline 42. & Maria: & I don't know \\
\hline 43. & ANNIKA: & If you take away O, the first O in Olle, what do you have? \\
\hline 44. & Olle: & If you take away... \\
\hline 45. & ANNIKA: & How can you find out? \\
\hline 46. & Olle: & That you spell \\
\hline
\end{tabular}

ANNIKA, one of the teachers, picks up what has just been initiated by LINN and taken up by Maria. She wonders, within the play frame, what Maria's name would be "if the Letter Thief has stolen your M?" (turn 38), followed by her sounding the name. The play is maintained and developed through making the Letter Thief the actor even when the attention is directed to the emergent reading skill. The activity is still challenging to Maria, as shown by her answers: repeating her name (turn 39) 
and saying that she does not know (turn 42). Another child, Olle, also becomes involved in this challenge, by asking about his name (turn 40). This shows that the problem is shared, that is, children and teachers are engaged in the same activity, even if the children do not know the answer. To ask (relevant) questions in an activity is an important aspect of showing knowledgeable participation. The teacher introduces a strategy for solving the problem, by posing a question about the initial letter (turn 43). She highlights the initial, the letter that should be taken away. Then she directs the children's attention toward a way to take on the challenge, or solve the problem (as is), when asking "How can you find out?" (turn 45). Olle suggests that one could spell (turn 46). In the next excerpt, Maria becomes engaged in the strategy that Olle suggested, to spell the name:

\section{Excerpt 11.6: Meta-communication Outside the Play Frame}

\begin{tabular}{l|l|l}
\hline 48. & LINN: & $\begin{array}{l}\text { Then what do you have? Try to find out. It seems tricky [the children have written } \\
\text { their names on the drawing, see Fig.11.2] Maria? Cover the M there. Then what } \\
\text { does it say? }\end{array}$ \\
\hline$[-]$ & & (ANNIKA talks with another child unrelated to the current activity) \\
\hline 53. & Maria: & $\begin{array}{l}\text { (has written 'aria' and now reads out what she has written) a-r-i-a, a-r-i-a, a-r-i-a, } \\
\text { aria! }\end{array}$ \\
\hline 54. & LINN & (with a happy-sounding voice) Yes, that's right! \\
\hline
\end{tabular}

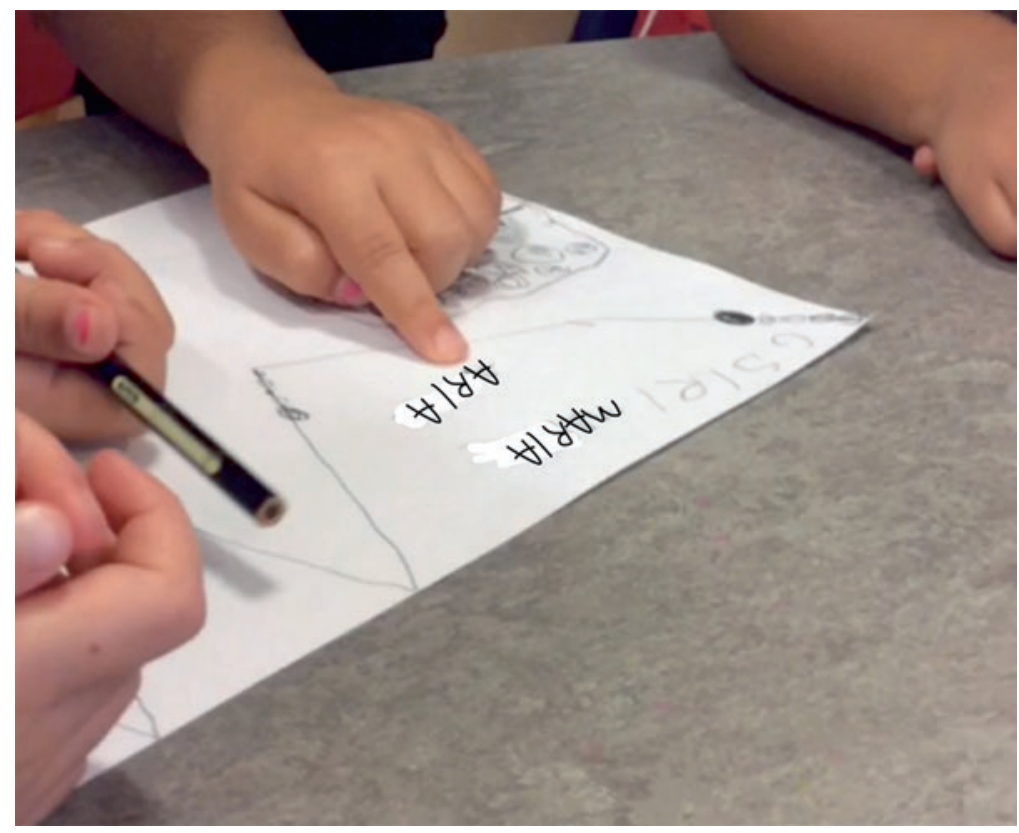

Fig. 11.2 Maria first writes her name and then only the letters that follow the letter M. Then she sounds what is written (the second word/name) accompanying her sounding with a finger 
The teacher guides Maria by saying what she can do to handle the task: "Cover the M there". Here meta-communication, outside the play frame (as is), is used in order to help Maria pay attention to the critical aspect of the phonetics and graphics of the name without the initial letter. Maria has written her name without an M, and she sounds it three times, then saying: "aria!" (turn 54). Now she answers the question asked by the teacher in a different, developed, way compared to how she did earlier (in Excerpt 11.5) when she repeated her name (turn 39).

\section{Excerpt 11.7: Maria is Appropriating the Strategy}

\begin{tabular}{l|l|l}
\hline 58. & ANNIKA: & But if you get your name tags, perhaps you can find out if you use those \\
\hline 59. & Maria: & Look! (has written lle) l-l-e, lle \\
\hline 60. & ANNIKA: & Yes, exactly! \\
\hline
\end{tabular}

The play-frame of the Letter Thief is backgrounded and the teacher suggests another way of handling the challenge, to use the signs with the children's names on (these are prepared for being used in different activities in the preschool), in order to facilitate the reading activity that is going on (turn 58). Reading is now a part of the play and the signs become structuring resources for it. Maria has during this time continued with the writing activity (see Excerpt 11.6) but this time she has written Olle's name (without the initial letter), in response to his question (turn 40, Excerpt 11.5). Maria directs the other participants' attention to what she has written, by exclaiming "look!" and sounding the written text once, and after that saying, "lle" (turn 59). Maria has now independently solved the problem that LINN introduced: she uses another name, chooses a strategy to handle the challenge - writing the name down without the initial letter, sounds the written text and then puts it together (i.e., reads it). In this way, Maria shows that she has appropriated the strategy that the teacher exemplified and then scaffolded her in taking over, but she also shows her changed understanding of 'stolen initial letter'. In other words, she shows insight in the content the teacher initiated and shared with the children in the playframe: what happens when you write and read a name without the initial letter (stolen by the Letter Thief).

\section{Excerpt 11.8: Maria is Given the Role of a More Competent Peer}

\begin{tabular}{c|l|l}
\hline 65. & ANNIKA: & (assists a child) Maria, can you help Niclas too? \\
\hline 66. & Maria: & (takes the name tag and sounds [she does not cover the N] \\
\hline 67. & Niclas: & If we take away N (puts his fingers over the N, see Fig. 11.3) \\
\hline 68. & Maria: & i-s-l-a-s, i-s-l-a-s, iklas \\
\hline 69. & ANNIKA: & $\begin{array}{l}\mathrm{C} \text { (points at the } \mathrm{C}, \text { which in the name Niclas sounds like a K; at the same time } \\
\text { as Maria sounds) }\end{array}$ \\
\hline
\end{tabular}

As the activity continues, Maria is given one more opportunity to deal with the content of learning highlighted by the challenge posed by the teacher; this time by 
Fig. 11.3 Niclas puts his finger on the initial letter $\mathrm{N}$ and Maria sounds (reads) the text/word

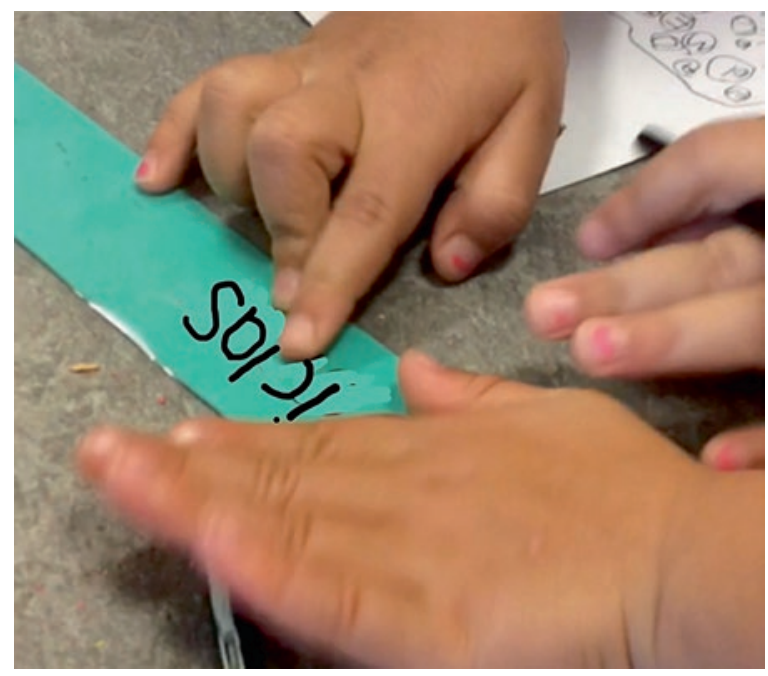

being asked to help another child: "Maria, can you help Niclas too?" (turn 65). In this way, Maria is given the role of, in Vygotskian terms, a more experienced peer in the activity. She shows that she has an idea about what the teacher means by immediately picking up the next name-sign (see Fig.11.3). Niclas covers the initial letter with his hand, suggesting that they take away the N (turn 67). In this way, he also shows an emerging understanding of the challenge and how to handle it. Maria sounds the letters after $\mathrm{N}$. The name includes an additional challenge due to the pronunciation of one of the letters, ' $\mathrm{C}$ '; in Swedish, this letter can be pronounced either as ' $\mathrm{S}$ ' [as in cereals] or (more infrequently) as ' $\mathrm{k}$ ' [as in Catherine]. Maria uses the more common way; "c" as "s" (turn 68). While Maria is sounding, the teacher says " $k$ " when pointing at the letter 'c' (turn 69). It seems to be taken for granted that this way of scaffolding without an explanation is enough, and understood by the children. In this way, the teacher meta-communicates about the reading activity (as is) and the activity then includes a classic element of teaching to read. This seems to be enough for Maria who changes her sounding of the character ' $c$ ' from 's' to ' $k$ ' and then reads the name "iklas" (turn 68).

\section{Excerpt 11.9: Reestablishing the Play Frame}

\begin{tabular}{|c|c|c|}
\hline 73. & ANNIKA: & What happens if the Letter Thief, hold it, takes my name, my first letter then? \\
\hline 74. & Child: & The you become... wait (says different words beginning with A) \\
\hline 75. & Maria: & $\begin{array}{l}\text { We have to find Annika's name. Where's Annika's name? Where is Annika's } \\
\text { name? }\end{array}$ \\
\hline 76. & $\begin{array}{l}\text { LINN \& } \\
\text { Child: }\end{array}$ & There, you had it there \\
\hline 77. & ANNIKA: & Does it have my name? \\
\hline 78. & Child: & No... there! (hands the sign to Maria) \\
\hline
\end{tabular}




\begin{tabular}{l|l|l}
\hline 79. & ANNIKA: & There it was \\
\hline 80. & Maria: & n-n-i-k-a (points at the letters while reading) nnika \\
\hline
\end{tabular}

ANNIKA links the content back to the narrative of the original play, that is, she recontextualizes the problem. She poses a new question about how her name would change if the initial letter of her name would be taken by the Letter Thief (turn 73). This becomes a repetition for the children of how the problem could be solved, now in the case of the name Annika. A couple of children have not appropriated the strategy that has been used to meet the challenge (to write, leaving the initial letter out or using the name signs) and they answer by suggesting words with 'A' as initial letter (turn 74). In contrast, Maria takes the initiative to find Annika's sign: "We have to find Annika's name. Where's Annika's name?" (turn 75). Several children, also the teachers, search among the signs to find Annika's sign. When the sign is found, Maria starts to read. She begins with the first ' $N$ ' and this time she only sounds once before she tells the name: "nnika" (turn 80). This shows that Maria has become familiar with the strategy (reading from the sign) but moreover what it means to separate the first sound of a word from the word as a whole.

\section{The Extended Content of Learning and Reestablishing Intersubjectivity}

The last excerpt shows how the content of learning is extended by a teacher. It is presented within the play frame: the Letter Thief might steal not only the initial letter but any of the letters of a name. However, at this time the children continue the play without taking on this developed challenge:

\section{Excerpt 11.10: A Potential Extension of the Challenge}

\begin{tabular}{l|l|l}
\hline 87. & Child: & The letter thief has taken your letter! [to SANNA] \\
\hline 88. & SANNA: & Which of my letters has he taken? \\
\hline 89. & Child: & It! \\
\hline 90. & SANNA: & And then what happens to the name? Did you find out? \\
\hline 91. & Maria: & (covers the S) a-n-n-a, anna! \\
\hline
\end{tabular}

A child invites SANNA to participate in the play, again by saying that the Letter Thief has stolen "your letter" (turn 87). In response, SANNA suggests a development of the play: that any of the letters of a name can be stolen: "Which of my letters has he stolen?" (turn 88). She illustrates that she is aware of both the play frame and the academic skill focused. At the same time, she opens up for a new challenge. This is done implicitly, that is with no explanation given that points out the difference to the earlier challenge. The children go on in the same way as earlier, by 
pointing out that the first letter is taken (turn 89). In other words, the teacher's proposal of developing the play is not at this point taken up by the children. Yet, there is temporarily sufficient intersubjectivity that allows the participants to continue the activity (the play) as earlier. The teacher follows the children's response, rather than explicitly meta-communicating the extended content, asking, "And what happens to the name? Did you find out?" (turn 90). Maria covers the initial letter, 'S' in Sanna, and sounds and reads the name (turn 91).

\section{Discussion}

In this chapter, we have analysed excerpts from a play activity, initiated by a group of children in which the teachers also become involved. The activity is analysed with respect to the concept of temporarily sufficient intersubjectivity (Rommetveit, 1974) and what this means to the continuation of activity (play). The analysis shows that the children and teachers share the problem (as is) and challenge (as if): discerning the initial letter and reading the name, beginning with the second letter, and they are engaged in the same activity; that is, some temporarily sufficient intersubjectivity is reestablished even if the children are unsure of how to handle the reading challenge.

The analysis also shows how the teachers introduce and establish a learning content that is a prototypical example of an academic skill (sounding and reading) within the play activity. This is done by explicitly communicating (metacommunicating) what is meant by the content that is challenging for the children. The explicit meta-communication of the teachers here appear to be needed for establishing intersubjectivity and opening up for learning opportunities regarding the proposed challenge. A way for the children themselves (without the teacher scaffolding) to regain intersubjectivity is to suggest starting the play over when they do not agree on something. This is a forceful strategy in order to be able to reestablish mutual play, since it is less demanding than through meta-communication clarifying what different participants mean and how these senses differ and can or cannot be reconvened within the scope of mutual activity.

In addition, to act and communicate as if appears as a way for the teachers to become participants in the play but also for scaffolding the children's participation in play and in other cultural practices (such as reading). In Excerpt 11.2, for example, the teacher asks about the thief as if he exists in reality, "have you seen him?", and in this way shows that she is part of the play world. When the situation requires clarification, for example in Excerpt 11.8 when they read the name "Niclas", the teacher switches to an as-is mode (saying how 'c' should be pronounced in the context of the name it is part of). This can be done without breaking the play-frame, even if temporarily leaving the as-if mode. Instead, it opens up for a possibility for the children to appear as more knowledgeable, according to Vygotskian reasoning (Vygotsky, 1998). The analysis implies that when introducing what for the children 
is a new content, meta-communication was necessary in order to make this content and its features visible to the children.

The analysed activity is also a nice example of appropriation (Wertsch, 1998), that is, learning, within a play frame. Maria in her first attempts do not know what her name would sound like without its initial letter. Through a process of scaffolding she appropriates an understanding of what is asked and a strategy for taking it on. She repeatedly uses this strategy during the course of the activity, for example when scaffolding other children to take on the challenge.

\section{References}

Lave, J., \& Wenger, E. (1991). Situated learning: Legitimate peripheral participation. New York, NY: Cambridge University Press.

Rommetveit, R. (1974). On message structure: A framework for the study of language and communication. London, UK: Wiley.

van Oers, B. (1998). From context to contextualizing. Learning and Instruction, 8(6), 473-488.

Vygotsky, L. S. (1997). The collected works of L. S. Vygotsky, Volume 4: The history of the development of higher mental functions (R. W. Rieber, Ed. \& M. J. Hall, Trans.). New York: Plenum Press.

Vygotsky, L. S. (1998). The collected works of L. S. Vygotsky, Volume 5: Child psychology (R. W. Rieber, Ed. \& M. J. Hall, Trans.). New York: Plenum.

Wertsch, J. V. (1998). Mind as action. New York, NY: Oxford University Press.

Open Access This chapter is licensed under the terms of the Creative Commons Attribution 4.0 International License (http://creativecommons.org/licenses/by/4.0/), which permits use, sharing, adaptation, distribution and reproduction in any medium or format, as long as you give appropriate credit to the original author(s) and the source, provide a link to the Creative Commons licence and indicate if changes were made.

The images or other third party material in this chapter are included in the chapter's Creative Commons licence, unless indicated otherwise in a credit line to the material. If material is not included in the chapter's Creative Commons licence and your intended use is not permitted by statutory regulation or exceeds the permitted use, you will need to obtain permission directly from the copyright holder.

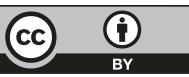

